\title{
The Effectiveness of Flipbook and Video to Improve Students' Critical Thinking Skills in Science Learning during the COVID-19 Pandemic
}

\author{
Ulin Nuha*, Sri Wahyuni, Aris Singgih Budiarso, Uswatun Hasanah, Novita Eka \\ Anggraeni \\ Science Education, Faculty of Teacher Training and Educaion, University of Jember, \\ Indonesia \\ *Corresponding Author Email: ulin.fkip@unej.ac.id
}

\author{
Article History \\ Received: April 2021 \\ Accepted: May 2021 \\ Published: June 2021 \\ Key Words \\ Flipbook; video; critical \\ thinking skill; COVID-19 \\ pandemic
}

How to cite this article?

\begin{abstract}
Critical thinking is one of the skills that must be possessed in studying science. During the Covid-19 pandemic, flipbooks and videos can be used as alternative media to improve students' critical thinking skills. This study aims to determine the effectiveness of using flipbooks and videos in improving the critical thinking skills of junior high school students during the pandemic. The method used in this research is descriptive quantitative. The data collected were in the form of students' pretest and posttest scores. The data were analyzed using the $\mathrm{N}$-gain test and Independent Sample T-Test. The results showed: (1) learning videos were effective for improving students' critical thinking skills with an average score of 0.44 (medium) and (2) flipbooks were effective for improving students' critical thinking skills with an average score of 0.42 (medium). There is no significant difference between students' critical thinking skills, both after using flipbooks and videos.
\end{abstract}

Nuha, U., Wahyuni, S., Budiarso, A., Hasanah, U., \& Anggraini, N. (2021). The Effectiveness of Flipbook and Video to Improve Students' Critical Thinking Skills in Science Learning during the COVID-19 Pandemic. Lensa: Jurnal Kependidikan Fisika, 9(1), 32-37. doi:https://doi.org/10.33394/j$\underline{1 \mathrm{kf} . \mathrm{v} 9 \mathrm{i} 1.3899}$

\section{INTRODUCTION}

Natural Sciences is a systematic study of everything related to phenomena that occur in nature (Hidayati, 2016). Science learning is carried out in a structured manner by exploring, conducting experiments, concluding, and compiling theories about natural phenomena (Wedyawati \& Lisa, 2019). Science learning has a purpose to introduce nature in a structured manner. Science learning does not only teach knowledge in the form of facts, concepts, principles, and processes in an invention (Oktaviana et al., 2020).

One of the skills that must be possessed in studying science is critical thinking skills. Through critical thinking, students will be able to evaluate evidence, assumptions, logic, and language from other people's statements (Asih, 2018). Critical thinking skills can retread students in solving problems that occur in everyday life (Nasihah et al., 2020). The critical thinking skills of students in Indonesia are still relatively low because the media used in learning is less innovative (Fatahullah, 2016). In addition, the low critical thinking skills of students are also caused by the teacher-centered learning process so that students are not trained to think critically (Nuryanti et al., 2018).

The Covid-19 pandemic presents its challenges in learning science. Online learning in the era of the pandemic and the new normal is unavoidable. The implications of government policy result in major changes to the education world. The science learning process that was previously carried out offline using real objects must be arranged in such 
a way that it can be done online. Online learning is expected to hone students' critical skills. One of the factors that can support an effective science learning process is learning media. The media that can be used are flipbooks and learning videos.

Flipbooks are sheets of paper resembling albums or calendars measuring approximately $21 \times 28 \mathrm{~cm}$ (Nursetyo, 2011). Learning materials can be presented in the form of a flipbook with an attractive selection of words, pictures, and colours. One of the advantages of flipbooks is that they can be presented in electronic format so that learning is more interactive and interesting. The results of research conducted by Aprilia (2021) showed that the score of critical thinking skills of students who used flipbooks was higher than the scores of students who used science textbooks.

In addition to flipbooks, videos are often used in science learning to hone students' critical thinking skills during the pandemic. The advantages of learning videos are that they are easy to see and hear repeatedly and can stimulate students' senses to obtain clear information (Pagarra \& Idrus, 2018). The results of the research by Septianty et al. showed that students' critical thinking skills increased by $70 \%$ after using learning videos.

Previous research has shown that both videos and flipbooks are effectively used in learning activities. In contrast to previous studies, this study was conducted to compare the effectiveness of the two media in the science learning process during the pandemic. Based on this background, this study was conducted to determine and compare the effectiveness of using flipbooks and learning videos in improving the critical thinking skills of junior high school students in science learning during the pandemic.

\section{METHOD}

This research is quantitative descriptive. The sample in this study was seventh-grade junior high school students in Jember and Banyuwangi. The sampling technique used is simple random sampling. Data was collected by giving a test before and after using flipbooks and learning videos. This study used the test and non-test instruments. The data obtained were in the form of pretest and posttest scores. The pretest was used to measure the initial critical thinking skill, while the posttest was used to measure the students' skills after using the flipbook or video. Each item in the pretest and posttest indicates each component in critical thinking skills. The non-test instruments used were observation sheets and interviews. Flipbook and learning video used in this study are learning media that have been validated by the experts. The data were analyzed using N-Gain to determine the effectiveness of flipbooks and learning videos. N-gain is a comparison of the actual gain score with the maximum gain score. The actual gain score is the gain score obtained by the student, while the maximum gain score is the highest possible score obtained by the student. Here is the N-Gain formula (Hake, 1999). Criteria of N-Gain are shown in Table 1.

$$
\mathrm{N}-\text { Gain }=\frac{\text { (postest score })-(\text { pretest score })}{(\text { maximum score })-(\text { pretest score })} \times 100 \%
$$

The score of critical thinking skills was then analyzed by using the Independent Sample T-test. This test was conducted to determine whether there were differences in the improvement of students' critical thinking skills after using flipbooks and learning videos. Independent Sample T-Test was performed using SPSS.

Table 1. Criteria of N-Gain

\begin{tabular}{cc}
\hline Interval & Criteria \\
\hline $\mathrm{G} \geq 0.7$ & High \\
$0.3 \leq \mathrm{G}<0.7$ & Medium \\
$\mathrm{G}<0.3$ & Low \\
\hline
\end{tabular}




\section{RESULTS AND DISCUSSION}

Science learning in the odd semester of 2020/2021 is carried out online. Flipbooks and learning videos are used as innovative media to support online learning. The pretest was given before using the flipbook and the posttest was given after the students used the flipbook. In the pretest and posttest scores, various criteria were obtained in each indicator which included 6 indicators according to Facione (2013), namely interpretation, analysis, evaluation, inference, explanation, and self-regulation.

The effectiveness of flipbooks in improving critical thinking skills can be seen from the increase in test results. Table 2 shows the recapitulation of pretest and posttest scores and the results of the $\mathrm{N}$-gain analysis.

Table 2. The recapitulation of pretest and posttest before and after using flipbook

\begin{tabular}{clcccc}
\hline \multirow{2}{*}{ No } & \multirow{2}{*}{ Critical Thinking Indicator } & \multicolumn{2}{c}{ Score } & \multirow{2}{*}{ N-Gain } & Criteria \\
\cline { 3 - 5 } & Pretest & Posttest & & \\
\hline 1 & Interpretation & 31 & 56 & 0.36 & Medium \\
2 & Analysis & 19 & 81 & 0.77 & High \\
3 & Inference & 8 & 50 & 0.46 & Medium \\
4 & Evaluation & 22 & 72 & 0.64 & Medium \\
5 & Explanation & 69 & 69 & 0 & Low \\
6 & Self-regulation & 69 & 78 & 0.29 & Low \\
\hline & Mean & 36.3 & 67.6 & 0.42 & Medium \\
\hline
\end{tabular}

N-Gain analysis (Normalized Gain) is used to measure the improvement of students' critical thinking skills before and after using flipbooks. Based on the N-Gain score on each indicator, it can be seen that: (1) the analysis is included in the high category; (2) interpretation, inference, and evaluation are included in the medium category; and (3) explanation and self-regulation are included in the low category. The overall average of indicators shows that students' critical thinking skills are in the medium category.

Based on Table 2, flipbooks can improve students' critical thinking skills on each indicator. This is following Aprilia's (2021) study which showed that the use of contextualbased flipbook media was able to improve students' critical thinking skills. The advantages of flipbooks in this study are the presentation of text, images, animations, and videos that are equipped with tools and connections so that students can navigate, interact and communicate. Another opinion suggests that the virtual module in the form of a basic multimedia flipbook with digital techniques can make learning materials easy to understand by students and can increase motivation, interest, and learning activities, as well as students' reading speed when using digital books (Hayati, et al, 2015; Huang \& Liang, 2015)

Tabel 3 The recapitulation of pretest and posttest before and after using Video

\begin{tabular}{cccccc}
\hline \multirow{2}{*}{ No } & \multirow{2}{*}{ Critical Thinking Indicator } & \multicolumn{2}{c}{ Score } & \multirow{2}{*}{ N-Gain } & \multirow{2}{*}{ Kriteria } \\
\cline { 3 - 4 } & Pretest & Pretest & & \\
\hline 1 & Interpretation & 237 & 307 & 0.35 & Medium \\
2 & Analysis & 235 & 307 & 0.36 & Medium \\
3 & Inference & 279 & 367 & 0.56 & Medium \\
4 & Evaluation & 212 & 351 & 0.38 & Medium \\
5 & Explanation & 282 & 410 & 0.87 & High \\
6 & Self-regulation & 250 & 298 & 0.14 & Low \\
\hline & Mean & 249.17 & 340 & 0.44 & Medium \\
\hline
\end{tabular}


Table 3 shows the recapitulation of students' pretest and posttest scores before and after using learning videos. Based on the N-Gain score for each indicator, it can be seen that: (1) the explanation is included in the high category; (2) interpretation, analysis, inference, and evaluation are included in the medium category; and (3) self-regulation is included in the low category. The overall average of indicators shows that students' critical thinking skills are in the medium category.

The use of learning videos is also able to improve students' critical thinking skills in science learning. This is in accordance with the research of Septianty et al (2018) which shows that learning videos can improve students' critical thinking skills. According to Hadi (2017), learning videos can improve conceptual understanding, learning motivation, and student learning outcomes. The ease of replaying video and the information presented in a structured manner make video one of the media that can improve students' ability to understand a concept. Another advantage is that videos can meet the needs of all students who have different learning characters (audio, visual, or audio-visual), can present events that are impossible for students outside of school to experience. It makes video an alternative media that is suitable for use in online learning during this pandemic.

Table 4. The Result of Independent Sample T Test

\begin{tabular}{cccccccc}
\hline Media & N & N-Gain & Mean & SD & Mean Difference & $\mathbf{p}$ & T \\
\hline Flipbook & 6 & 0,42 & 42.17 & 26.87 & 2.17 & 0.887 & 0.145 \\
Video & 6 & 0,44 & 44.33 & 24.79 & & & \\
\hline
\end{tabular}

The results of the independent sample t-test showed that the probability value or sig. (2-sided) is 0.887 (greater than 0.05) which means that $\mathrm{H} 0$ is accepted. This means that there is no significant difference in the value of students' critical thinking skills after using flipbooks and learning videos. The mean difference is 2,167 with the interval of difference range from 35,454 to 31,121 . Based on table 3 , the coefficient value $t_{\text {count }}(0.145)$ is smaller than the coefficient value $t_{\text {table }}(2.228)$ so that $\mathrm{HO}$ is accepted. This means that there is no significant difference in students' critical thinking skills, both after using flipbooks and after using videos.

The results of data analysis show that the use of flipbooks and videos is effective in improving students' critical skills. Based on the independent sample T-Test result, there is no significant difference in the effectiveness of flipbooks and learning videos in improving students' critical thinking skills. Both flipbooks and videos are classified as multimedia which contains audiovisual elements. Flipbooks and learning videos are alternative media that are suitable for the science learning activity during the pandemic. During the pandemic, students should be able to learn independently in online learning activities. According to Daryanto (2010), multimedia in learning must be able to provide opportunities for students to control the pace of learning and reading independently (Daryanto, 2010).

\section{CONCLUSION}

Flipbooks and videos are ICT-based learning media that can be used as an alternative in the online science learning process during the pandemic. Based on the results of data analysis, the use of flipbooks and learning videos can improve the critical thinking skills of junior high school students. Both flipbook and video media can improve critical thinking skills in the medium category. The increase obtained after using the flipbook was not significantly different from the increase obtained after using the learning video. 


\section{RECOMMENTATION}

This study was conducted to determine and compare the effectiveness of flipbook and video media in science learning. Further research is needed to determine the effectiveness of other innovative media that can be an alternative in science learning during the Covid 19 pandemic. In addition, it is necessary to develop other innovative media to improve 21 st-century skills through online learning.

\section{ACKNOWLEDGMENT}

This research received no specific grant from any funding agency in the public, commercial, or not for profit sectors.

\section{REFERENCES}

Aprilia, T. (2021) Efektivitas Penggunaan Media Sains Flipbook berbasis Kontekstual untuk Meningkatkan Kemampuan Berpikir Kritis. Jurnal Penelitian Ilmu Pendidikan, 14 (1), 20210, 10-21.

Asih, A. G., Sudarmin, \& Sri, M. (2018). Keefektifan Video Pembelajaran Etnosains dalam Model Pembelajaran Direct Instruction Terhadap Berpikir Kritis Siswa. Chemistry In Education, 7(2), 41-45.

Daryanto. (2010). Media pembelajaran. Yogyakarta: Gava Media.

Facione. (2013). Critical Thinking: What It Is and Why It Counts. Measured Reasons and The California Academic Press, Millbrae, CA.

Fatahullah, M. M. (2016). Pengaruh Media Pembelajaran Dan Kemampuan Berpikir Kritis Terhadap Hasil Belajar IPS. Jurnal Pendidikan Dasar, 7(2), 237-252

Hadi, S. (2017). Efektivitas Penggunaan Video sebagai Media Pembelajaran untuk Siswa Sekolah Dasar. Prosiding TEP \& PDs: Transformasi Pendidikan Abad 21, Tema 1, Nomor 15, Mei 2017.

Hake, R. (1999). Analyzing Change/ Gain Score. Indiana: Indiana University.

Hayati, S., Budi, A. S., \& Handoko, E. (2015). Pengembangan media pembelajaran flipbook fisika untuk meningkatkan hasil belajar peserta didik. Prosiding Seminar Nasional Fisika (e-Jurnal) SNF2015.

Hidayati, N. (2016). Pembelajaran Discovery Disertai Penulisan Jurnal Belajar Untuk Meningkatkan Kemampuan Kerja Ilmiah Siswa Kelas VIII. 1 SMP NEGERI 1 Probolinggo. Jurnal Penelitian Pendidikan IPA, 1(2), 52-61.

Huang, Y. M., \& Liang, T. H. (2015). A technique for tracking the reading rate to identify the e-book reading behaviors and comprehension outcomes of elementary school students. British Journal of Educational Technology, 46(4), 864-876. https://doi.org/10.1111/bjet.12182.

Nasihah, E. D., Supeno, dan A. D. Lesmono. (2020). Pengaruh Tutor Sebaya Dalam Pembelajaran Problem Based Learning Terhadap Keterampilan Berpikir Kritis Fisika Siswa SMA. Jurnal Pendidikan Fisika, 8(1), 44-57.

Nuryanti, L., Zubaidah, S. and Diantoro, M. (2018). Analisis Kemampuan Berpikir Kritis Siswa SMP. Jurnal Pendidikan: Teori, Penelitian, dan Pengembangan, 3(2), 155-158.

Oktaviana, D., I. K. Mahardika, dan A. S. Budiarso. (2020). The Effectiveness of Guided Inquiry Learning Assisted By Phet Simulation to Improve the Capability of Representation Image of Science Student in Junior High School. ScienceEdu, 3(2), 43-47.

Pagarra, H., N. A. Idrus. (2018). Pengaruh Penggunaan Video Pembelajaran IPA Terhadap Minat Belajar Siswa Kelas III SD Impres Lanraki 2 Kecamatan Tamalanrea Kota Makassar. Jurnal Publikasi Pendidikan, 8(1), 30-40. 
Wedyawati, N., Y. Lisa. (2019). Pembelajaran IPA Di Sekolah Dasar. Yogyakarta: Deepublish. 